\title{
7
}

\section{Planning, Design, Assessment, and Engagement Processes for Greyfield Precinct Regeneration}

\section{A Framework for Smart Regenerative Urban Development at Precinct Scale}

Previous chapters have shown that delivering more-sustainable regenerative development increases in complexity as urban scale increases and as focus shifts to redeveloping existing urban fabrics, especially greyfields (Fig. 7.1). Here, key objectives relate to jointly increasing the supply of medium-density housing, retrofitting urban infrastructures (energy, water, mobility, and waste management) to make them distributed, lowcarbon, and regenerative, increasing the mix of residential and commercial land uses to create neighbourhoods that are more productive and liveable, and greening streetscapes by redistributing and reconfiguring land previously allocated to automobile use for nature-based services to accommodate pressures from climate change and densifying suburbs. We have called the integration of these urban performance factors greyfield precinct regeneration. Its goals are set out in Table 7.1 as a list of urbandesign objectives.

There is a critical relationship between all the elements in the precinct design and assessment process (Fig. 7.2). The ability to positively 


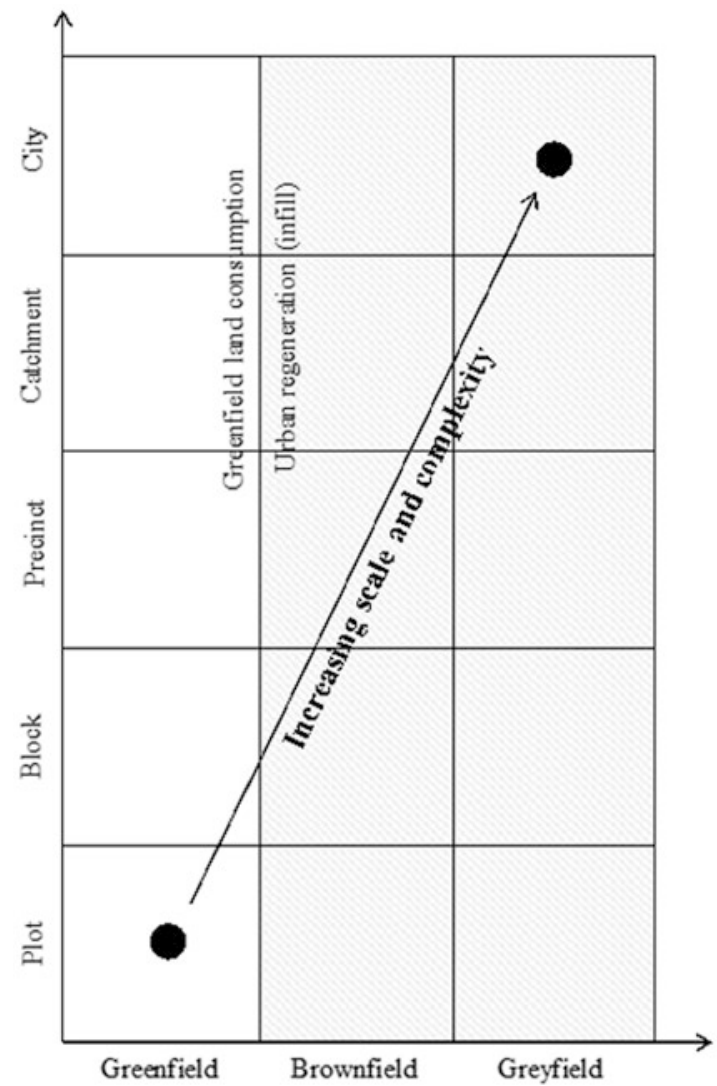

Fig. 7.1 Urban arenas and scale of urban redevelopment. (Source: Adapted from Thomson, 2016)

influence the cost and performance of a precinct design project is always highest at the front end, in the concept-design-feasibility stages, a period during which information to aid decision-making in a timely manner has proven more difficult to assemble. It is for this reason that increasing attention is being paid to new processes, instruments, and platforms that can be introduced for smarter precinct planning and design at concept and design phase (Newton \& Taylor, 2019) to address the assessment deficit that currently exists for urban-design practitioners in both private and public sectors (but local government development assessment in 
Table 7.1 Dimensions of urban performance requiring a precinct planning and design response

\begin{tabular}{|c|c|}
\hline Domains & $\begin{array}{l}\text { Objectives of regenerative precinct-scale planning and } \\
\text { design. }\end{array}$ \\
\hline Housing & $\begin{array}{l}\text { Greater dwelling yield; variety and flexibility in designs, } \\
\text { floor areas, layouts; underground parking; costing, } \\
\text { market feasibility, and affordability assessment. }\end{array}$ \\
\hline Energy & $\begin{array}{l}\text { Zero carbon energy; distributed renewable energy and } \\
\text { storage and electric vehicle (EV) recharging; } \\
\text { microgrids; community renewable energy } \\
\text { opportunities, including peer-to-peer energy trading; } \\
\text { electricity self-sufficiency/export to grid. }\end{array}$ \\
\hline Water & $\begin{array}{l}\text { Opportunities for integrated water system: stormwater } \\
\text { capture, rainwater harvesting and greywater recycling } \\
\text { for non-potable uses; water-sensitive urban design. }\end{array}$ \\
\hline Waste & $\begin{array}{l}\text { Optimised recycling of C\&D waste from demolitions; } \\
\text { introduction of food waste composting systems for } \\
\text { medium density and high-rise apartments. }\end{array}$ \\
\hline Mobility & $\begin{array}{l}\text { More walkable neighbourhood designs; less area } \\
\text { devoted to cars on private property and in public } \\
\text { realm; greener streets and rain gardens on verges } \\
\text { seamlessly meshed to private green spaces; car sharing; } \\
\text { ride sharing; e-mobility. }\end{array}$ \\
\hline Communications & $\begin{array}{l}\text { High-speed fibre network to the node and ubiquitous } \\
\text { broadband services to neighbourhood premises. }\end{array}$ \\
\hline Green space & $\begin{array}{l}\text { Maintain, rather than lose, canopy trees associated with } \\
\text { urban development and redevelopment; activate and } \\
\text { revegetate local streets and nearby pocket parks; } \\
\text { redistribute sections of road space to green-space. }\end{array}$ \\
\hline Safety & $\begin{array}{l}\text { Design safety and security in at a neighbourhood scale; } \\
\text { over-sight of walkways and public spaces; } \\
\text { 'neighbourhood watch'. }\end{array}$ \\
\hline $\begin{array}{l}\text { Distributed urban } \\
\text { services }\end{array}$ & $\begin{array}{l}\text { Distributed energy systems, integrated water systems, } \\
\text { waste micro-factories, food-waste composting, and } \\
\text { car-sharing systems linked with a precinct scale of } \\
\text { urban development; precincts as micro-utilities. }\end{array}$ \\
\hline Integrated design & $\begin{array}{l}\text { Precincts can be an integrator of all the built- } \\
\text { environment objects and flows that feature in urban } \\
\text { design at this scale; for example, buildings + land uses } \\
\text { + open space + transport systems + utility } \\
\text { infrastructures (water, sewerage, electricity, gas, } \\
\text { communications); employing integrated urban } \\
\text { modelling: BIM building information modelling + PIM } \\
\text { precinct information modelling + CIM city information } \\
\text { modelling. }\end{array}$ \\
\hline
\end{tabular}


Table 7.1 (continued)

\begin{tabular}{|c|c|}
\hline Domains & $\begin{array}{l}\text { Objectives of regenerative precinct-scale planning and } \\
\text { design. }\end{array}$ \\
\hline Place-making & $\begin{array}{l}\text { Placed-based approaches to urban planning and design } \\
\text { need to draw on new precinct-scale knowledge, } \\
\text { frameworks, and instruments to deliver } \\
\text { neighbourhoods where people want to live. }\end{array}$ \\
\hline $\begin{array}{l}\text { Precinct, } \\
\text { neighbourhood, } \\
\text { district } \\
\text { performance rating }\end{array}$ & $\begin{array}{l}\text { Industry-supported voluntary rating systems are } \\
\text { emerging in Australia and overseas that are designed } \\
\text { to guide and encourage the development of more- } \\
\text { sustainable urban communities; for example, NCOS- } \\
\text { Precincts, Green Star Communities, } \\
\text { EnviroDevelopment, and One Planet Communities in } \\
\text { Australia; LEED-Neighbourhood Development, } \\
\text { EcoDistricts, CASBEE, and BREEAM for Communities all } \\
\text { operate internationally. Many elements of these need } \\
\text { to become mandatory and linked with scientifically } \\
\text { verifiable assessment tools if a transition to sustainable } \\
\text { urban development is to be realised. }\end{array}$ \\
\hline
\end{tabular}

Source: Adapted from Newton (2019)

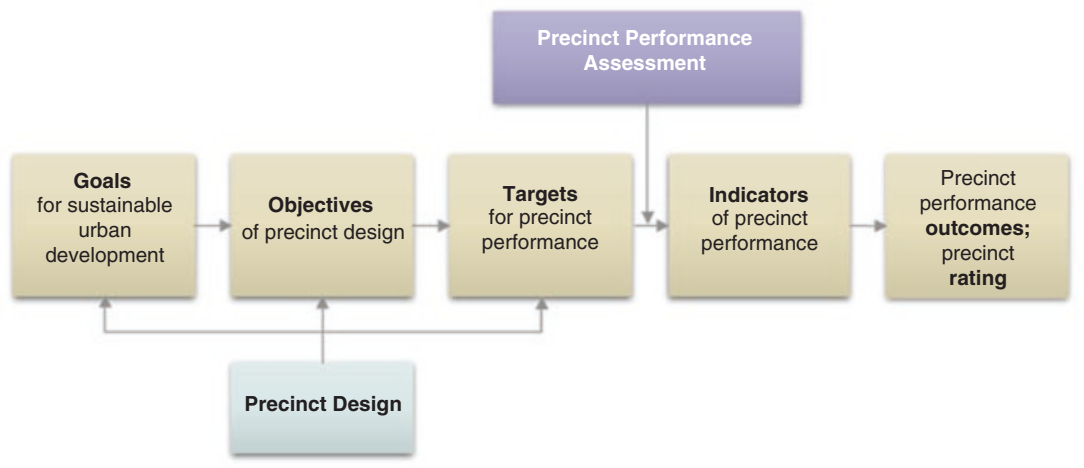

Fig. 7.2 Key processes underpinning greyfields precinct regeneration. (Source: Newton, 2019)

particular). They enable more rapid and iterative assessment of precinct design performance (against objectives) to assess economic feasibility as well as present proof of the additionality that the project delivers to local government and community residents. Both are critical to the GPR model of redevelopment. 
Regenerative redevelopment in the greyfields requires land assembly and the greater potential for additionality that a larger site allows. Most redevelopment to date in established suburbs has been small-scale, fragmented, speculative knock-down-rebuild where a single site is purchased and 1:1-4 new dwelling units built on the block in conformance with existing local government building and planning regulations. Residential development in the middle suburbs of Australian cities has typically created lots ranging in size between $400 \mathrm{~m}^{2}$ and $800 \mathrm{~m}^{2}$ (average $600 \mathrm{~m}^{2}$ ), with the original dwelling occupying approximately a third of this space, the rest being permeable open space and driveways/parking spaces. Housing redevelopment outcomes for small-lot subdivision vary slightly in terms of both dwelling outcomes and site layout (Table 7.2). The small-lot subdivision model has proven to be economically viable and highly replicable, but it does not contribute sufficiently to greyfield net infill housing supply or enable urban redevelopment at a scale and density that can effectively reshape and regenerate low-density suburbia and contribute to broader urban development goals, such as delivering environmentally sustainable outcomes for the future of Australia's fastgrowing cities.

An alternative approach to land assembly at a larger (precinct) scale is required in greyfields. Locally organised housing development models driven by a 'group of individuals acting together on the basis of shared interest' (Crabtree, 2018) have emerged in Australia and internationally (Palmer, 2020; Sharam, 2016). They take various forms but are typically led by a 'developer' who aggregates demand for a medium-high-density housing project, enabling a site to be secured and design to be commenced following engagement with local government. Recruitment of participants is unconstrained spatially and is speculative. Getting such projects off the ground has proven difficult, especially those associated with attempts to deliver more socially and environmentally responsive medium-density housing aligned with local government strategic development plans and design guides that require increased levels of sustainability performance (https://nightingalehousing.org/).

GPR is a variant of locally organised housing development models to the extent that it is likely to be a municipality-initiated process requiring 
Table 7.2 Typical scales and configurations of greyfield residential redevelopment

\begin{tabular}{|c|c|c|c|}
\hline Precinct type & Lot type & $\begin{array}{l}\text { Net new } \\
\text { dwellings }\end{array}$ & Plan \\
\hline $\begin{array}{l}\text { Small-lot subdivision } \\
\text { (SLS): }\end{array}$ & $\begin{array}{l}\text { Wide lot, difficult } \\
\text { with side }\end{array}$ & 1 & \\
\hline SLS: Battle-axe & $\begin{array}{l}\text { House located } \\
\text { towards front or } \\
\text { back }\end{array}$ & 1 & \\
\hline SLS: Corner site & $\begin{array}{l}\text { Any site abutting } \\
\text { two roads }\end{array}$ & $1-2$ & \\
\hline SLS: Terraced & Long lot & $2-3$ & \\
\hline $\begin{array}{l}\text { SLS: Joint } \\
\text { development }\end{array}$ & Two adjoining lots & $4-6$ & \\
\hline $\begin{array}{l}\text { Greyfield precinct } \\
\text { regeneration: } \\
\text { Requires } \\
\text { amalgamation of } \\
\text { several adjoining } \\
\text { properties }\end{array}$ & $4+$ lots & $10+$ & \\
\hline
\end{tabular}

Source: Adapted from the Victorian Department of Environment, Land, Water and Planning, Housing Development Data, spatial layer

resident engagement and support at a neighbourhood level, responding to the locality's clearly identifiable, place-specific, strategic development needs. As outlined in Chap. 2, GPR's emergence as a new regenerative model for city redevelopment requires alignment of metropolitan and local government strategic and statutory planning (e.g., district greenling) and a municipality's preparedness to initiate a new level of 
engagement with local communities associated with the need for and benefits of local-area change.

Unsolicited bids from developers are an alternative model for transitactivated or place-activated GPR projects that are entrepreneurial, involving land development as a way of paying for the investment. Another possible GPR model would be top-down interventions from state and federal governments. These are all unlikely to be major contributors to greening the greyfields, as most development is a partnership between developers/owners and local governments. Thus, the model outlined in this chapter is a municipality-initiated process requiring partnerships with the owners and the potential developers. This model is developed further in Chap. 8. the current chapter focuses on a development model that is working in its early stages in the City of Maroondah in Melbourne. The process pioneered by the Greening the Greyfields team in the City of Maroondah and in dialogue with the Victorian State Government is set out below as a model for step-wise creation of greyfields precinct regeneration. The project is closer to a place-activated GPR than a transitactivated GPR.

\section{Governance Processes for Greyfield Precinct Renewal}

\subsection{Declaration of Greyfields as Areas Capable of Delivering More Housing Supply, Choice, and Diversity}

Based on the body of work undertaken by the Greening the Greyfields project, GPR now exists as a new policy and planning directive in Plan Melbourne 2017-2051; this is a signal to local government of the need to create new pathways for urban infill in established suburbs (see Box 7.1): 


\section{Box 7.1 Policy 2.2.4—Provide Support and Guidance for Greyfield Areas to Deliver More Housing Choice and Diversity}

Greyfield sites are residential areas where building stock is near the end of its useful life and land values make redevelopment attractive. Melbourne has many residential areas that qualify as greyfield sites, particularly in established middle and outer suburbs. These areas often have low-density, detached housing on suburban-sized allotments that have good access to public transport and services. Until now, the redevelopment of these areas has been generally uncoordinated and unplanned. That must change. Greyfield areas provide an ideal opportunity for land consolidation and need to be supported by a coordinated approach to planning that delivers a greater mix and diversity of housing and provides more choice for people already living in the area as well as for new residents. Methods of identifying and planning for greyfield areas need to be developed. A more structured approach to greyfield areas will help local governments and communities achieve more sustainable outcomes.

Source: Plan Melbourne 2017-2050 (p. 51) (https://www.planmelbourne. vic.gov.au/_data/assets/pdf_file/0007/377206/Plan_Melbourne_2017-2050_ Strategy_.pdf)

This was an important step, as it gave credibility to the underlying research and encouragement to both the professionals in local government and the consultants who were trying to deliver it.

\subsection{A Broad Analysis of an Entire City's Potential for Greyfield Regeneration Needs to Become Part of Future Metropolitan Strategic Planning Processes}

In Chap. 1, a metropolitan-wide assessment of residential redevelopment potential undertaken for Melbourne established that over one-third of the city's 32 municipalities had more than half their housing stock with high redevelopment potential. Ideally, the district greenlining process referred to in Chap. 1 becomes a key step in a city's urban regeneration strategy and process, incorporating the longer-term infrastructure retrofit plans of major water, energy, and waste utilities. A governance model for long-term integrated planning involving utilities, transport, and state 
and municipal planners that spans the scales from macro to micro level and can become a guide to GPR (both place- and transit-activated) remains to be developed. Even where district greenlining processes are absent at metro level, they are nonetheless possible at municipal level where GPR needs to be activated.

\subsection{Locate Candidate Precincts for GPR at Municipal Level: Data Analytics}

An analysis of individual residential properties within municipalities using the ENVISION tool provides the starting point for assessing where there is potential for precinct-scale redevelopment. Speculative developers would use the software's basic 'market assessment' RPI outputs to identify properties where value is largely in the land and business-asusual, small-lot-subdivision redevelopment is prospective.

Municipal planners, however, require a broader analysis that can encompass additional local area redevelopment issues that address area regeneration and community benefit - what we have termed additionalities - that can be delivered as part of a GPR project. They cover the list of precinct-regeneration objectives in Table 7.1. ENVISION also enables multi-criteria analysis of property redevelopment potential in a municipality that can incorporate many of these objectives, providing an evidence base for change in municipal land use, transport, and housing strategies that are both near-term and long-term in nature. By switching specific property and area attributes on or off, ENVISION highlights locations where there is a cluster of properties with high redevelopment potential and neighbourhood features that support higher-density development (such as proximity to public transport, shops, and schools) as well as well as potential for landscape redesign and activation from various perspectives (e.g., flood mitigation, urban greening, or more-walkable streets). Figure 7.3 shows very clearly why the rather dominant blue of the solely market-based RPI becomes a series of stronger colours; indicating why municipal issues are so important to incorporate as well as RPI. Indeed, municipality-initiated or supported GPR is premised on 


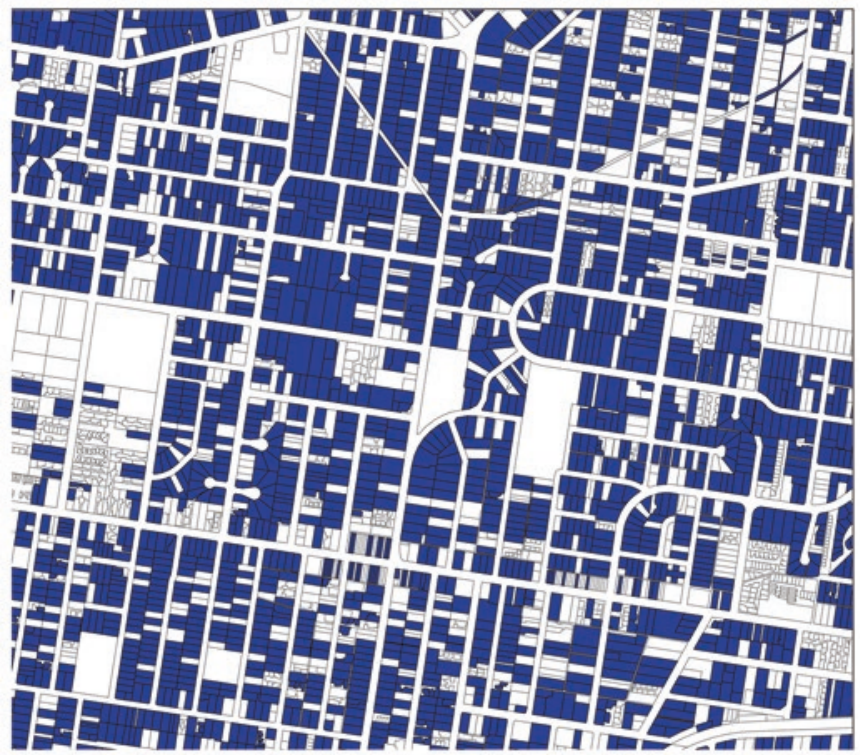

Market Analysis
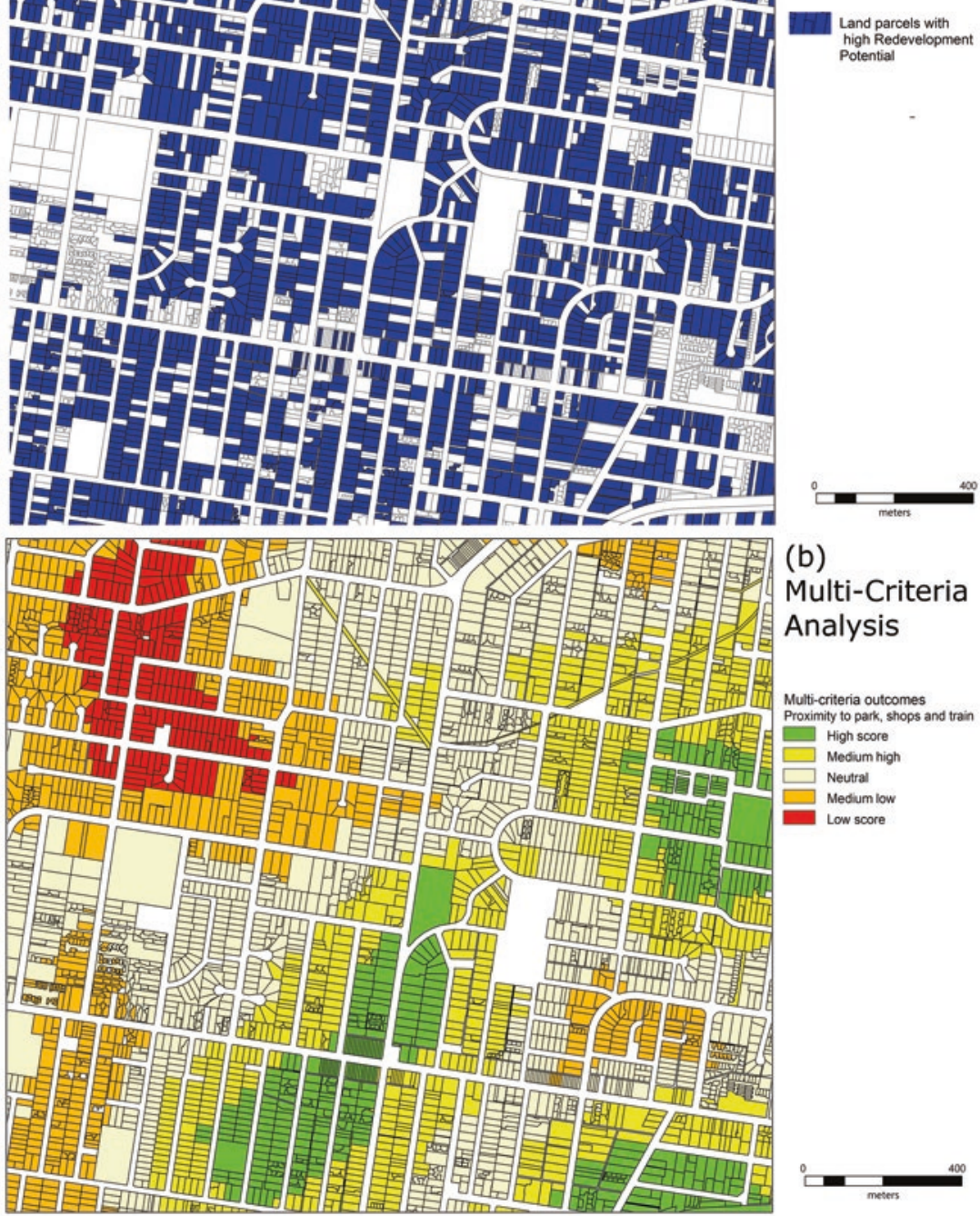

(b)

Multi-Criteria Analysis

Multi-criteria outcomes Proximity to park, shops and train

High score

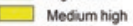

$\square$ Neutral

Medium low

Low score

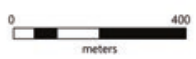

Fig. 7.3 ENVISION analysis of residential redevelopment potential (a) and multiple-criteria-assessment of redevelopment context (b). (Source: data set derived from more than 20 Victorian Government data sets) 
achieving additionality and common-good outcomes for the local community as well as increased housing supply.

Identifying and agreeing on the best of the candidate sites requires judgements that are political as well as technical; thus, a final set of steps is needed. Obtaining broad stakeholder involvement is how good politicians and their technical advisers find the best way through a range of options. Below are the steps taken with the selected stakeholder groups to choose specific areas within the municipality.

\subsection{Identify GPR Precincts for Rezoning: Municipal-Community-State Government Engagement}

Data on residential redevelopment potential alone are unlikely to gain municipal support for a GPR rezoning. Rather, the various arms of municipal government need to be engaged, so that the full range of government, community, practitioner, and political stakeholders can have input to the process. This tiered and multi-faceted method incorporates a plurality of voices in the co-creation of outcomes. Outlined below is the process pioneered in the City of Maroondah:

- Local government officers: A whole-of-organisation working group was established across all relevant sections of the municipality, including engineering, parking, planning, community engagement, and openspace and asset management, to consider ENVISION analyses within the context of municipal-development priorities and policies. A set of workshops between these groups identified places within the municipality that had current or emerging challenges and where precinctscale regeneration was a desirable intervention. An output from these workshops was a map of potential GPR precincts, each with its prospective precinct additionality. In the City of Maroondah, key additionalities sought for the candidate precincts were flood mitigation, enhanced walkability, and green space, in addition to medium-density housing redevelopment. Municipal officers and consultants undertook scoping studies for each issue. 
- Community engagement: On advice from community-engagement officers, a validation exercise was initiated with community representatives selected from a range of local issues-based groups in response to a call for an expression of interest. This led to a parallel process with a community advisory group of 20 members whose role was to identify priority areas for future redevelopment/revitalisation.

- Municipal sign-off: The selection of priority precincts for piloting GPR was a strategic and political decision made by the director of planning, taking into consideration the level of support at community and councillor levels. Figure 7.4 shows the first pilot precinct identified, comprising approximately 200 mostly greyfield houses, and its key additionality objectives.

- Municipal-state government engagement for statutory planning change: To deliver greater housing yields and development additionalities, precinct-scale regeneration requires adapting existing planning instruments and legislation so that property owners and developers have clarity about their rights and obligations, and that the additionality incorporated into specific redevelopment proposals can be effectively governed and enforced. Methodologically, this stage of research involved three phases: first, to ascertain what degree of statutory change was viable for an existing residential zone and the proposed future form of redevelopment; second, to iterate prospective planning changes with urban designers, municipal planners, and domain experts (lawyers, engineers, and quantity surveyors); and third, to iterate and agree on the acceptable form of the statutory change with state planning authorities. The initial set of methods to promote lot amalgamation juggled a 'carrot or stick' approach by considering:

- Restricting single-lot redevelopment through increasing setbacks and minimum lot sizes.

- Controlling development through consistency with an incorporated plan, effectively enforcing amalgamation to deliver medium density.

- Simplifying the development process for integrated (amalgamated) projects, thus rewarding developers with faster approval times. 


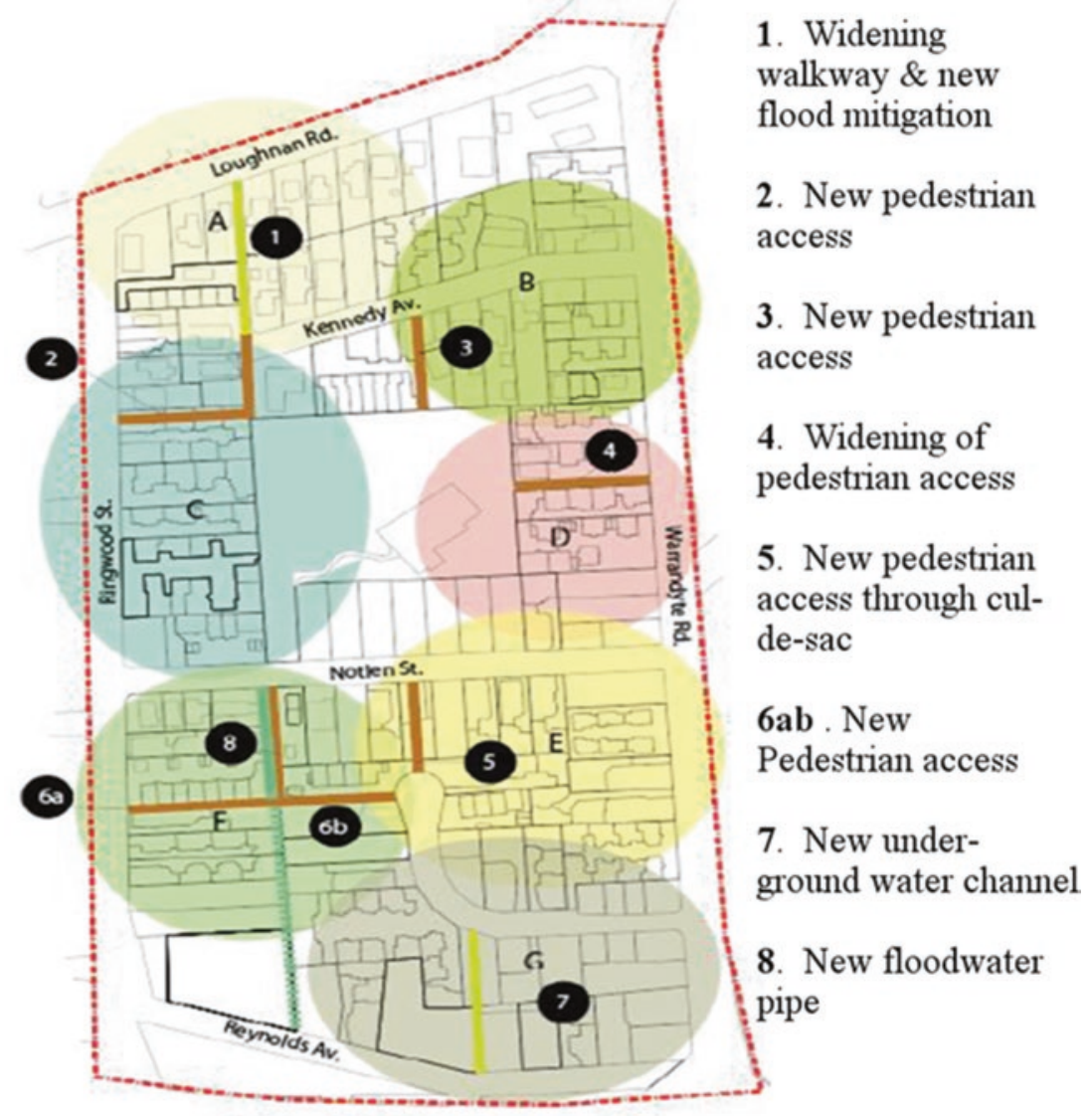

Fig. 7.4 Priority precinct for GPR process implementation with identified redevelopment additionalities. (Source: https://yoursay.maroondah.vic.gov.au/ c134maro-ringwood, Retrieved 2 March 2021)

- Applying development contributions to fund precinct additionality.

- Setting out Neighbourhood Character objectives that promote future character associated with precinct-scale medium density.

The set of potential planning tools included: 
- A software toolkit for precinct design assessment that can be used by urban-design practitioners as well as municipal planning officers in the Development Assessment process to quantify the performance/additionality delivered by a specific GPR project (Newton \& Taylor, 2019; CRCWSC, 2021). Chapter 8 explores prospects for an automated Precinct Information Modelling tool and a digital platform for integrated modelling, experimentation, and decision-making capable of accelerating and mainstreaming the precinct design and assessment process.

- A Design and Development Overlay: Where specific forms of development (single-lot subdivision) are not supported, but new forms of development (medium density requiring lot amalgamation) are supported in the schedule to the overlay.

- An Incorporated Plan Overlay or Development Plan Overlay, where a built form that achieves the outcomes of the overlay is exempt from notice (advertising), objection, and third-party review; again rewarding the developer if the outcomes are appropriate. Incorporated Plan Overlays are based on plans provided by developers to suit the context; Development Plan Overlays are based on municipal plans.

- A Neighbourhood Character Overlay: Where the future preferred form is defined in a schedule to the overlay. This effectively works like a Heritage Overlay in reverse, and focuses on the future character.

- Public Acquisition Overlay: Where land is compulsorily acquired for public benefit. This overlay is rarely used due to the significant public backlash it generally creates.

- Developer Contribution Plan Overlay: Sets out requirements to pay contributions towards specified infrastructure; it needs to be developed concurrently with a plan incorporated into the planning scheme.

\subsection{Establish Normal Planning Processes for GPR Precincts: Municipal-State Government Processes}

Workshops with state and local government planners identified three main topics that a new planning scheme needed to address for GPR to proceed: precinct and housing design, precinct additionality, and the cost 
of governance and infrastructure. These factors guided the creation of new statutory outcomes through a Development Plan Overlay, combined with a Developer Contribution Plan Overlay necessary to capture a proportion of development/project value to be used on fulfilling 'off-site' precinct additionality work (Fig. 7.5 provides a workflow diagram of this process).

A precinct plan that incorporated dwelling design and precinct additionality elements was rendered as a visual plan for the overlay. The schedule of the overlay (the text defining the rules and obligations) was then drafted to enshrine the preferred types of development. The design guides and other relevant information were placed into the scheme as

\section{Internal process}

Community and political buy-in

Locate precincts

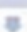

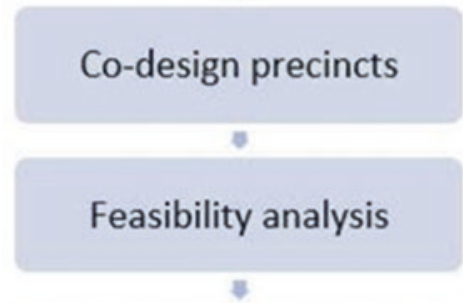

Establish statutory change required

Amendment submission

\section{Public/legal process}

*

Seek authorisation to prepare amendment

Public Exhibition of amendment

Recieve community submissions

Planning panel recomendations

Amendment submission to minister

Amendment approval

Fig. 7.5 Key processes for GPR land-use amendment 
incorporated documents and reference documents. The package of all documents was drafted within the (state government-provided) planningprovisions template and presented to the state planning authority to be considered as an amendment to the Municipal Planning Scheme.

Together these documents covered the explicit outcomes developers must deliver to comply with the desired planning outcomes. Should developers comply with the code, and if lot amalgamation were to occur, one additional storey was provided (on lots over $2000 \mathrm{~m}^{2}$; enabling the development of four-storey buildings to a height of $14 \mathrm{~m}$ ), and thirdparty objections were removed. The removal of third parties' rights to object was granted since residents had been engaged and had had the opportunity to object during the advertising process of the new overlay. Objections after its passing were therefore considered invalid. These documents have been submitted to the public exhibition phase of the Victorian government's planning amendment process (represented in Fig. 7.6) and titled Amendments C134-Maroondah, C136-Maroondah. At the time of writing, these Amendments have satisfied all municipal and state planning assessments by the Victorian Planning Panels and have been approved for ministerial signing (Planning Panels Victoria, 2021; again, see Figure 7.5). The Victorian Planning Authority and the City of Maroondah are collaborating to develop a business model for the GPR scheme and an appropriate model of governance, final steps in the precinct regeneration process in order to mainstream and scale up.

This section has set out the planning processes that are needed to accomplish greyfield precinct regeneration. They may appear complicated, but a novel planning solution requires testing to ensure it doesn't fail for lack of forethought or process. However, once the pilot is underway and begins being mainstreamed, the process is expected to become much simpler, as all necessary steps will be known and understood among stakeholder groups (as occurred with brownfield regeneration after the Building Better Cities program). Technical and community stakeholders as well as developers will acquire a sense of trust and confidence in the planning system. 


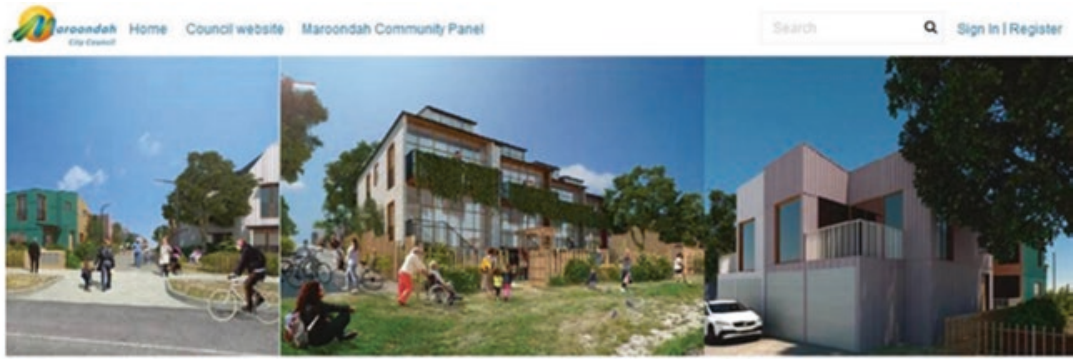

Amendment C134maro - Ringwood Greyfield Precinct

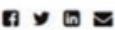

Submissions for this Amendment have now closed.

Maroondah Caty Council has prepared Amendment C134 to the Maroondah Planning Scheme. Amendment C134maro applies to the Ringwood Grejteld Predind bound by Loughnan Road to the north. Warrang,te Road to the east. Ringwoed Street to the west and the Ringwood B,pass to the south

The Amendment proposes to rezone the Precinct trom Neighoourhood Residental Zone to Generat Resioental Zone Scheoule 3 and inteouce a Development Pian Overiay Scheoule 7 and Develobment Cortributions Plan Scheoule 2 The Amendment also introouced the Design Framework and Concegt Pian. Ringwood Greviteld Precinct 2019 as a Reterence Document to the Uaroondah Planning Scheme. Other changes are atso proposed to the Municipal Strategic Statement and the Local Pianning Policy within the Haroondah Planning Scheme to suppont the strategic basis for the Amendment and update the policy application.

You may inspect the amendment any documents that support the amendment and the explanatory report about the amenoment at

- the Haroondah Cay Council website at www maroendah vic govaukbout Counclatave-yoursar?

- the Depantment of Endronment Land. Water and Planning webste www delo vic govaubublicinspection

Why person who may be atfected by the amendment can make a submission to the planning authonty about the Amendment Submissions must be made in writing and indude the submeters name and contad address. along with deaty stated prounds on which the Amendment is subcorted or ocposed. and indicating what changes (f anj) the submiter wishes to see made to the Amendment.

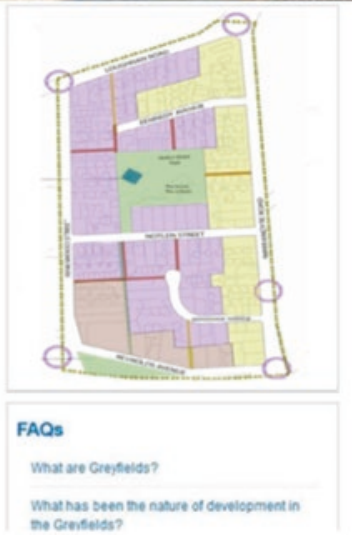

Fig. 7.6 City of Maroondah website for Amendment C134. (Source: https://yoursay.maroondah.vic.gov.au/c134maro-ringwood. Retrieved 2 March 2021)

\section{Design for Greyfield Precinct Regeneration}

In Chap. 1 it was claimed that GPR was not failing for lack of design innovation. On the contrary, many architects and urban designers and state government architect offices have illustrated what is possible in precinct-scale redevelopment (https://www.epw.qld.gov.au/about/initiatives/density-diversity-competition; https://www.governmentarchitect. nsw.gov.au/projects/missing-middle-design-competition). However, to date, planning had not been able to initiate such precinct-scale design-led initiatives in greyfields. This book, and in particular this chapter, has shown that planning can be unblocked to enable GPR projects. The 
chapter now turns to the key design principles for the place-activated GPR design principles and concepts that guided the City of Maroondah project.

The key precinct design principles and objectives outlined in Table 7.1 include attributes of liveability, sustainability, and climate-change resilience, most of which are deficient in state and local governments' current statutory urban-development assessment principles and practices. The following sections outline key steps in this process related to development of dwelling typologies and street typologies appropriate to regenerative precinct redevelopment in low-density greyfield suburbs. Design guides (examples are available at www.greyfields.com.au/documents) will also be required as an incorporated document in any amended local planning scheme and specific development overlays designed to provide the basis for a legislated design-based assessment instrument for any proposed new GPR projects.

\subsection{Dwelling Typologies}

Medium-density housing is the target for GPR, as it represents the most appropriate 'fit' for a sustainability transition in low-density urban fabrics in the Australian context (outside of activity centres and major transport corridors that have been zoned for higher-density apartment development). The high demand for well-located medium-density housing was illustrated in Chap. 6.

To address the context of the locality, as well as to test the performance of selected housing designs, a set of medium-density dwelling typologies were developed, where the boundaries of statutory planning regimes, building codes, environmental performance, financial feasibility, and community acceptance could be tested. Figure 7.7 illustrates a selection of designs developed for this study, and Table 7.3 lists their attributes. These designs represented a set of dwellings that could be included in candidate GPR projects at sketch level for purposes of visualisation (e.g., 'fit' with neighbourhood), as well as performance assessment against a set of precinct design principles and objectives.

Candidate precincts ranged from single-lot subdivisions to four lotamalgamation developments, featuring residential densities up to 200 


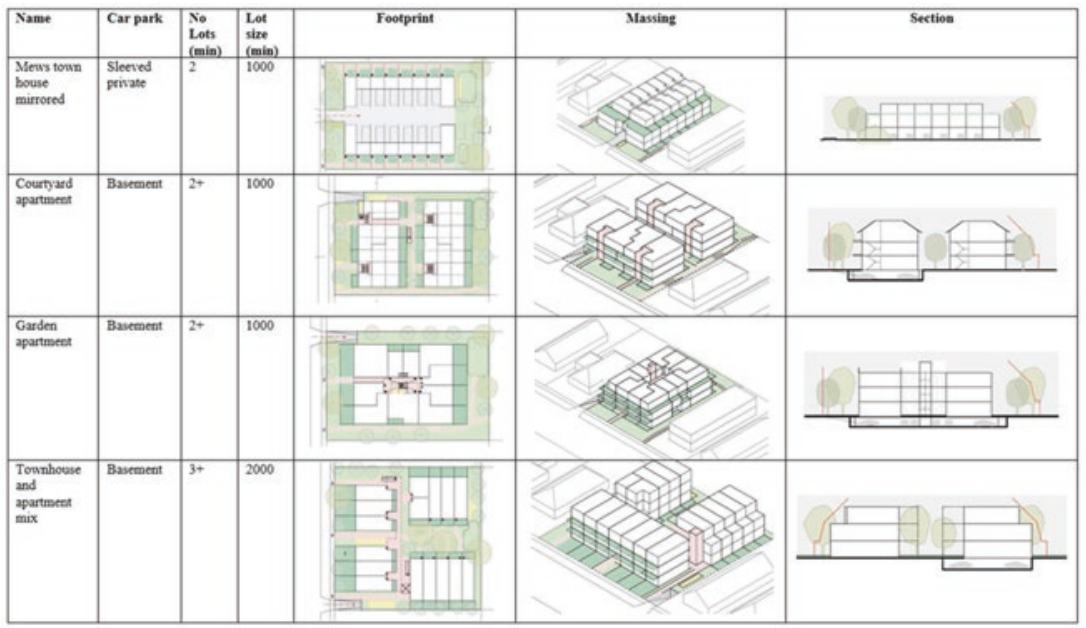

Fig. 7.7 Multi-lot dwelling typologies. (Source: Newton et al., 2020)

dwellings per hectare. They were all scalable to more lots and precinct sizes. Opportunities for underground parking increased as developable lot sizes increased, making underground parking an option. In all cases, the following attributes were included: lot-coverage remained at roughly $50 \%$ of hard-surface coverage area; underground parking was planned to ensure space for deep-root canopy trees; public and private space was provided for all typologies; and all walkable surfaces were semi-permeable. Most typologies had a range of unit types, all of which were above industry standard in terms of floor-area requirements. All typologies were assessed against statutory regimes and passed existing regulations for the General Residential Zone. This provided a focus for the GPR overlay zoning where a transition from Neighbourhood Residential Zone to General Residential Zone was proposed as a minimum shift in building and planning controls.

Each state's planning provisions contains residential zones that provide for a range of intensities of development outcomes. Though the names and legislative underpinnings vary, they can largely be referred to as 'nogo' (highly restricted redevelopment), 'slow-go' (limited redevelopment), and 'go-go' (large-scale redevelopment), which are described for all capital cities in Table 1.1. Application of specific zones sets the built-form 
Table 7.3 Attributes of dwelling typologies selected for GPR

\begin{tabular}{|c|c|c|c|c|}
\hline Typology & Mews & Courtyard & $\begin{array}{l}\text { Garden } \\
\text { apartment }\end{array}$ & $\begin{array}{l}\text { Townhouse- } \\
\text { apartment mix }\end{array}$ \\
\hline Site area $\left(m^{2}\right)$ & 1350 & 1350 & 1350 & 2070 \\
\hline N. lots & 2 & 2 & 2 & 3 \\
\hline N. dwellings & 16 & 24 & 26 & 32 \\
\hline N. car parks & 12 & 22 & 30 & 37 \\
\hline Density (d/ha) & 118.5 & 177.8 & 192.6 & 154.6 \\
\hline Floor area ratio & 1 & 0.8 & 0.8 & 0.9 \\
\hline Dwelling footprint $\left(\mathrm{m}^{2}\right)$ & 700 & 658 & 699 & 1007 \\
\hline Open space $\left(m^{2}\right)$ & 650 & 692 & 651 & 1063 \\
\hline * Private & 146 & 176 & 171 & 405 \\
\hline * Common & 418 & 427 & 480 & 494 \\
\hline * As balcony & 168 & 128 & 220 & 316 \\
\hline * Driveway & 178 & 27 & 27 & 27 \\
\hline * Semi-permeable & 74 & 124 & 63 & 291 \\
\hline Front setback (m) & 5.5 & 7 & 7.5 & 6 \\
\hline Side setback (m) & 3.8 & 2.4 & 4.3 & 3 \\
\hline Rear setback $(m)$ & 7 & 7 & 9 & 2.8 \\
\hline Site coverage & $52 \%$ & $49 \%$ & $52 \%$ & $49 \%$ \\
\hline Hard surface & $10 \%$ & $2 \%$ & $2 \%$ & $1 \%$ \\
\hline Soft landscaped & $42 \%$ & $45 \%$ & $48 \%$ & $43 \%$ \\
\hline Semi permeable & $5 \%$ & $9 \%$ & $5 \%$ & $14 \%$ \\
\hline Communal open space & $31 \%$ & $32 \%$ & $36 \%$ & $24 \%$ \\
\hline Private open space & $11 \%$ & $13 \%$ & $13 \%$ & $20 \%$ \\
\hline \multirow[t]{3}{*}{ Dwelling size $\left(\mathrm{m}^{2}\right)$} & 60 & $75(2 \mathrm{BR})$ & $43(1 \mathrm{BR})$ & 50 (1BR) \\
\hline & (1BR) & & 66 (2BR) & $100(2 \mathrm{BR})$ \\
\hline & $\begin{array}{l}102 \\
(2 \mathrm{BR})\end{array}$ & & & 145 (3BR) \\
\hline \multirow[t]{4}{*}{ Dwelling mix } & $12 \times$ & ALL 2BR & $16 \times 2 B R$ & $6 \times 3 B R$ \\
\hline & $2 \mathrm{BR}$ & & $14 \times 1 \mathrm{BR}$ & $22 \times 1 \mathrm{BR}$ \\
\hline & $4 \times 1$ & & & $4 \times 2 B R$ \\
\hline & $\mathrm{BR}$ & & & \\
\hline $\begin{array}{l}\text { Semi-permeable open } \\
\text { space / dwelling }\left(\mathrm{m}^{2}\right)\end{array}$ & 37 & 16 & 12 & 15 \\
\hline $\begin{array}{l}\text { Semi-permeable open } \\
\text { space / dwelling }\left(\mathrm{m}^{2}\right)\end{array}$ & 37 & 30 & 30 & 35 \\
\hline N. trees & 12 & 12 & 15 & 22 \\
\hline
\end{tabular}

and regeneration outcomes, and by altering the zone it is possible to alter expected outcomes. Furthermore, and if there is capacity in the precinct, rezoning could also be written to incorporate precinct-specific additionalities. 


\subsection{Street Typologies and Activation}

Given the significant loss of private green space associated with current patterns of greyfields development, there is increased pressure on streetscapes to perform many of the functions traditionally part of the residential lot: activation for recreation and play, providing space for more biodiversity, canopy trees, flood-water mitigation, and provision for parking. In automobile-dependent suburbs, more land is typically devoted to roads and parking than housing (Litman, 2018), and more road space is dedicated to motorised transport than to pedestrian and cycling modes, even in the Netherlands (Nello-Deakin, 2019). A recent study in Melbourne has also revealed that more than one-third of public green space is road verge (Marshall et al., 2019). Place-activated GPR should afford a significant redistribution of street space (see Murray et al., 2015).

Street typologies were created for the Maroondah pilot precincts to optimise redevelopment options for two of Council's additionality targets: retention of green space (especially canopy trees) and flood mitigation. Design focus was on also on enhancing connectivity and safety on the street to promote streetscape activation simultaneously with precinct regeneration; and to increase the amenity of the streets by altering traffic flow and parking. Figure 7.8 presents a range of scenarios, each of which increases the sustainability metrics of the streetscape (Table 7.4). The scenarios, all of which were verified by municipal engineers and statutory planners for compliance, include:

1. Existing road alignment retained, $4 \mathrm{x}$ bio-swales on southern verge to width of parallel parking bays

2. Existing road alignment retained, $1.5 \mathrm{~m}$ footpath on southern verge, $4 \mathrm{x}$ bio-swales southern side to width of parallel parking bays

3. Road and turning head realignment, $5.5 \mathrm{~m}$ roadway, $\mathrm{T}$-junction head, $1.5 \mathrm{~m}$ footpath at front of kerb, bioswales along full-length southern verge and indented to parallel parking northern verge

4. As above with footpath at rear of kerb 


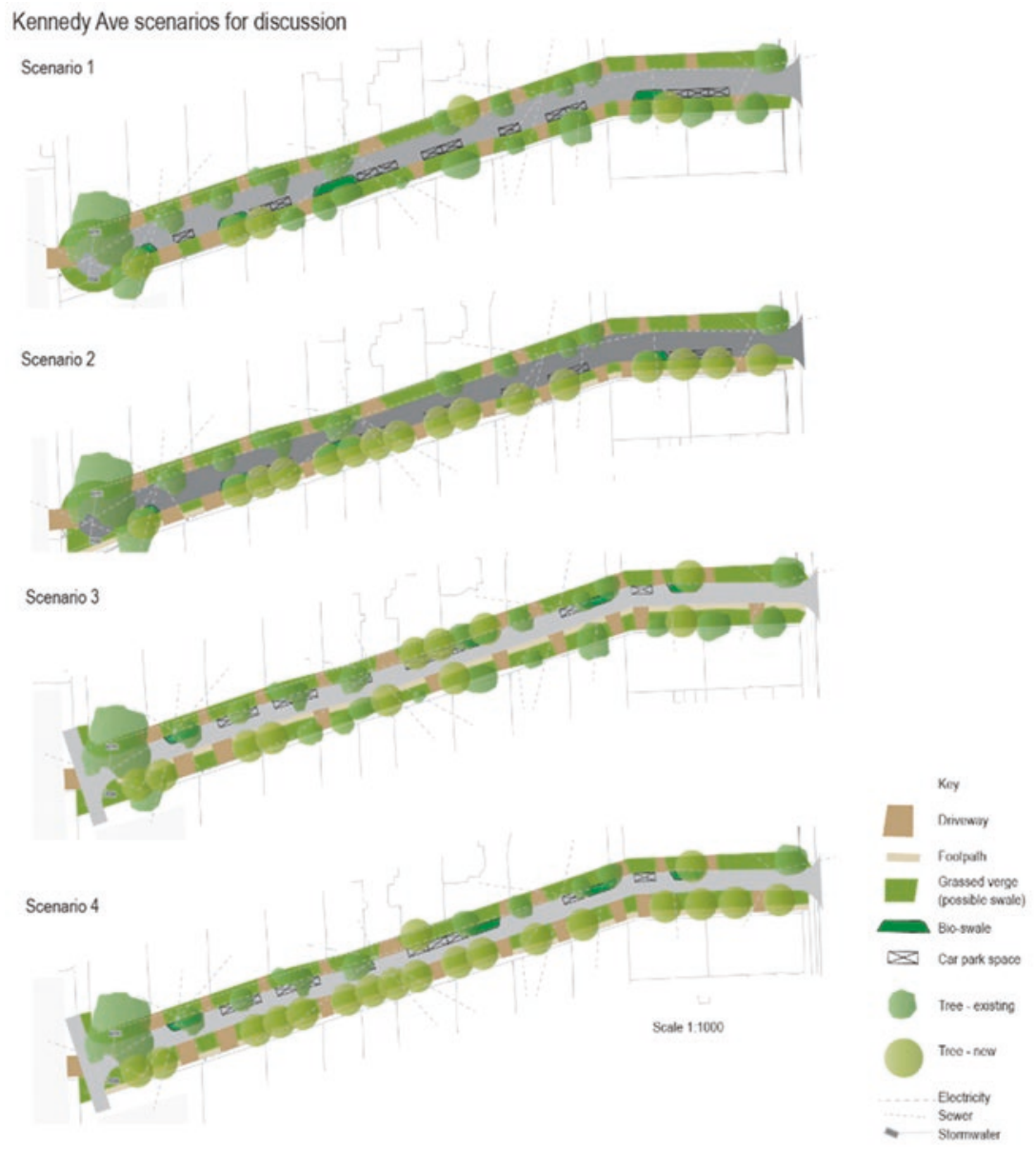

Fig. 7.8 Streetscape redesign options. (Source: Maroondah City Council internal discussion paper)

These interventions show that canopy can be increased from the existing $36.5 \%$ coverage to between $45 \%$ and $56.2 \%$, and the STORM (Melbourne Water, 2020) rating can be improved from $0 \%$ to $107 \%$, indicating that the bioswales and permeable surfaces achieve a $100 \%$ STORM rating. They also indicate a $45 \%$ reduction in the typical annual load of total nitrogen and thus achieved target water-quality objectives. 


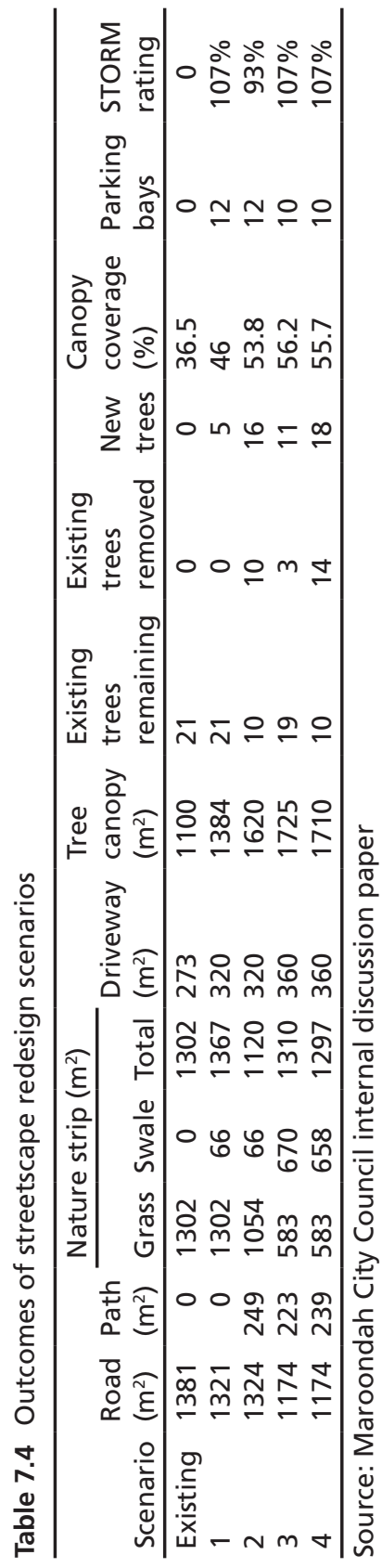




\section{$4 \quad$ Precinct Design Assessment Tools}

To establish the level of additionality arising from a redevelopment project requires formal quantitative assessment across key performance areas. There is currently a deficit of accessible precinct assessment tools for the urban-design professions (practitioners as well as those in local government; Newton, 2019); although, there is an emerging set of instruments from research groups that can be applied to this process (Newton \& Taylor, 2019).

A number of these, including CSIRO's latest NatHERS tool for assessing operating energy efficiency (www.nathers.gov.au) and CRC for Water Sensitive Cities' Urban Infill tool (Renouf et al., 2019) for assessing nature-based performance in areas such as rainwater capture, stormwater runoff, and evapotranspiration, were applied to the GPR pilot precinct in the City of Maroondah. Figure 7.9 shows the precinct identified by the City of Maroondah for GPR development, with the sub-precinct identified for performance assessment highlighted. The assessment examined three scenarios. The first assessed the 'existing' housing built mostly before 1970; all with high redevelopment potential but poor physical and

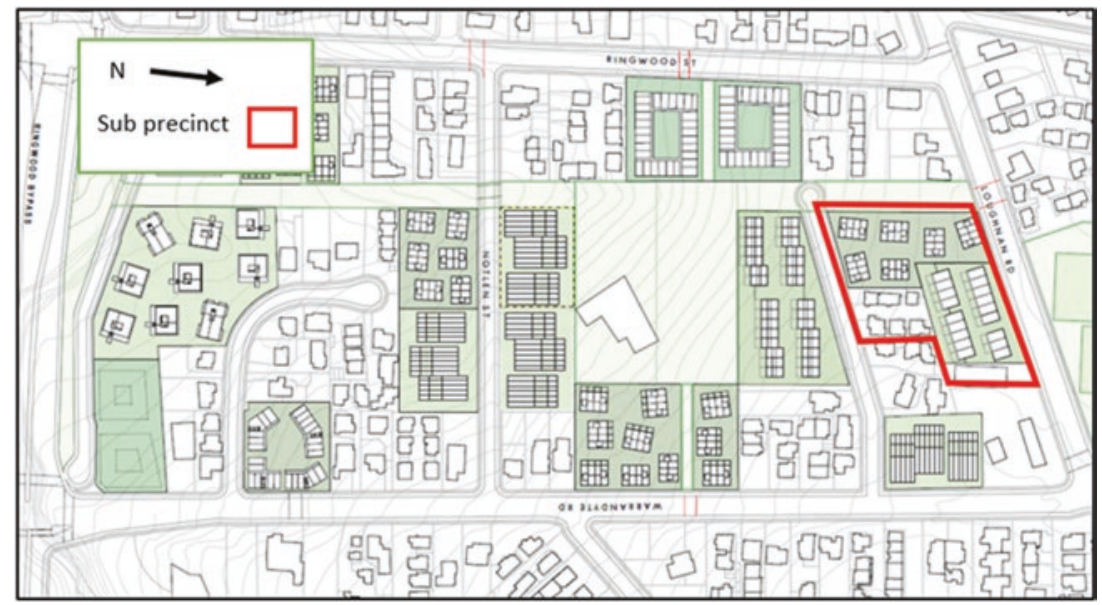

Fig. 7.9 GPR precinct in the City of Maroondah with representative housing typologies; sub-precinct for assessment highlighted 
environmental attributes. The second reflects outcomes if business-asusual housing redevelopment occurs at a rate of 2.3:1 (reflecting current knock-down-rebuild averages in the surrounding suburb). The thirdGPR - illustrates the outcomes of precinct-scale redevelopment that employs the typology 'Townhouse and apartment mix' (illustrated in a plan view of the redevelopment in Fig. 7.9).

Performance assessment was undertaken for the key domains listed in Table 7.5. The benefits of precinct regeneration reported here focus primarily on the immediate built-form innovations possible in the subprecinct under existing building and planning regulations:

Table 7.5 Precinct performance assessment across three development scenarios

\begin{tabular}{|c|c|c|c|}
\hline & \multicolumn{3}{|l|}{ Scenario } \\
\hline & $\begin{array}{l}1 . \\
\text { Existing } \\
\text { housing }\end{array}$ & $\begin{array}{l}\text { 2. Business-as-usual } \\
\text { (knock-down- } \\
\text { rebuild) } \\
\text { redevelopment }\end{array}$ & $\begin{array}{l}\text { 3. Regenerative } \\
\text { precinct } \\
\text { redevelopment } \\
\text { (existing regulations) }\end{array}$ \\
\hline $\begin{array}{l}\text { Area of [sub] precinct } \\
\left(\mathrm{m}^{2}\right)\end{array}$ & 7472 & 7472 & 7472 \\
\hline \multicolumn{4}{|l|}{ Dwelling outcomes } \\
\hline \multicolumn{4}{|l|}{ Number of units } \\
\hline 1 bedroom & 0 & 0 & 8 \\
\hline 2 bedroom & 0 & 10 & 20 \\
\hline 3 bedroom & 11 & 15 & 20 \\
\hline Density (dwg/ha) & 15 & 33 & 64 \\
\hline Estimated population & 33 & 60 & 108 \\
\hline $\begin{array}{l}\text { Total precinct } \\
\text { building footprint } \\
\left(\mathrm{m}^{2}\right)\end{array}$ & 2291 & 3179 & 3138 \\
\hline Roof (\% of site) & 31 & 43 & 42 \\
\hline $\begin{array}{l}\text { Conditioned area of } \\
\text { all dwellings }\left(\mathrm{m}^{2}\right)\end{array}$ & 2291 & 3179 & 7512 \\
\hline \multicolumn{4}{|l|}{ Open space } \\
\hline $\begin{array}{l}\text { Non-permeable hard } \\
\text { surfaces }\left(\mathrm{m}^{2}\right)^{\mathrm{a}}\end{array}$ & 3884 & 5195 & 3587 \\
\hline Garden $\left(m^{2}\right)^{a}$ & 3520 & 2277 & 3885 \\
\hline $\begin{array}{l}\text { Non-permeable hard } \\
\text { surfaces }(\%)^{a}\end{array}$ & 52 & 70 & 48 \\
\hline $\begin{array}{l}\text { Garden }(\%) \\
\text { Trees }\end{array}$ & 48 & 30 & 52 \\
\hline Canopy $\mathrm{m}^{2 \mathrm{~b}}$ & 2011 & 886 & 2242 \\
\hline
\end{tabular}


Table 7.5 (continued)

\begin{tabular}{|c|c|c|c|}
\hline & \multicolumn{3}{|l|}{ Scenario } \\
\hline & $\begin{array}{l}1 . \\
\text { Existing } \\
\text { housing }\end{array}$ & $\begin{array}{l}\text { 2. Business-as-usual } \\
\text { (knock-down- } \\
\text { rebuild) } \\
\text { redevelopment }\end{array}$ & $\begin{array}{l}\text { 3. Regenerative } \\
\text { precinct } \\
\text { redevelopment } \\
\text { (existing regulations) }\end{array}$ \\
\hline $\begin{array}{l}\text { Canopy } \% \text { of } \\
\text { precinct }^{\mathrm{b}}\end{array}$ & 27 & 12 & 30 \\
\hline \multicolumn{4}{|l|}{ Parking (onsite) } \\
\hline Above ground (n) & 22 & 50 & 0 \\
\hline Below ground $(n)$ & 0 & 0 & 56 \\
\hline Total $\left(\mathrm{m}^{2}\right)$ & 440 & 1000 & 1120 \\
\hline Above ground $\left(\mathrm{m}^{2}\right)$ & 440 & 1000 & 0 \\
\hline \multicolumn{4}{|c|}{ Financials (total dwellings) } \\
\hline Sales value $(\$ 000)^{c}$ & 900 & 2250 & 3600 \\
\hline Value uplift $(\$ 000)^{c}$ & 0 & 1350 & 2700 \\
\hline Value uplift (\%) & 0 & 150 (approx.) & 300 (approx.) \\
\hline \multicolumn{4}{|l|}{ Energy } \\
\hline Star rating ${ }^{d}$ & 1.85 & 6 & 8 \\
\hline Total $\left(\mathrm{MJ} / \mathrm{m}^{2}\right)$ & 469 & 125 & 57 \\
\hline Heating $\left(\mathrm{MJ} / \mathrm{m}^{2}\right)$ & 281 & 75 & 36 \\
\hline \multicolumn{4}{|l|}{ Water } \\
\hline Runoff (ML/yr) & 1.78 & 2.44 & 1.63 \\
\hline $\begin{array}{l}\text { Evapotranspiration } \\
\text { (ML/yr) }\end{array}$ & 2.28 & 1.66 & 2.43 \\
\hline Infiltration (ML/yr) & 0.15 & 0.9 & 0.16 \\
\hline
\end{tabular}

Source: Newton et al. (2020)

aTaken from geospatial analysis of CAD drawings and aerial photos

' $T$ Taken from geospatial analysis of CAD drawings, aerial photos, and representative subdivisions locally for business-as-usual modelling

'Methodology based on sales values only. Full costings and methods are available in Planning Panels Victoria (2021)

'Based on consultant's modelling and averaging all dwellings in multi-unit subprecinct to eight-star, using NatHERS for Climate Zone 62, Moorabbin, in https:// www.nathers.gov.au/sites/default/files/2019-10/NatHERS\%20Star\%20bands.pdf 
- Housing diversity: Precincts have the capacity to deliver a greater variety of housing options, including size, layout, orientation, and price points.

- Compactness: The outcome of good precinct design reveals an almost doubling of the densities that can be achieved compared to businessas-usual. This supports the compact city agenda.

- Building footprint and permeability: The precinct footprint is roughly the same as business-as-usual, but due to optimised design can retain almost half the site area as permeable, as opposed to $30 \%$ for businessas-usual. This leads to one-third less stormwater runoff, $80 \%$ more rainwater infiltration, and 30\% higher evapotranspiration rates, reflecting an enhanced vegetation cover compared to business-as-usual development—a positive contribution to neighbourhood microclimate and climate-change adaptation.

- Energy: The existing housing was estimated to have an operating energy rating of 1.8 stars (Sustainability Victoria 2014), which equates to an average annual energy consumption of approximately $469 \mathrm{MJ} /$ $\mathrm{m}^{2}$. New dwellings are required to perform to currently mandated (business-as-usual) six-star ratings (approximately $125 \mathrm{MJ} / \mathrm{m}^{2}$ in Melbourne's climate). GPR precinct dwellings were designed to an eight-star energy rating $\left(54 \mathrm{MJ} / \mathrm{m}^{2}\right.$ per year, which can probably be met with the electricity produced from solar panels, depending on household energy-use practices). Inclusion of $2 \mathrm{~kW}$ solar photovoltaic power per dwelling (generating $2715 \mathrm{~kW}$ of electricity per year) provides the pathway to carbon-neutral performance for a household (Newton \& Tucker, 2010, 2011).

- Financials: Including the developer contribution plan for precinct additionalities, the additional densities arising from more-effective massing show that precinct value uplift is roughly double that of business-as-usual development (based on sales values), producing a return on investment of at least $20 \%$, based on a yield approximately double that of business-as-usual. An overview of the methodology can be found at https://greyfields.com.au/documents/. 


\section{Stakeholder Engagement}

While the successful outcome of the GPR project rests on the willingness of landowners to embrace the scheme, and thus will require significant engagement, there are also legislative requirements to accommodate prior to land-use change, and political risk-mitigation requirements to ensure that residents are socialised and supportive during the change. Some key steps and principles in the final stages of a place-activated GPR process are discussed in the following sections.

\subsection{Legislative Engagement and Political Risk-Mitigation}

Contemporary turns in planning have seen community engagement gain prominence as a critical aspect of governance (Aulich, 2009). Aside from reducing community opposition, good engagement practice increases sense of belonging and civic pride (Lawson \& Kearns, 2010), as well as improving the quality of urban planning projects (Jarvis et al., 2012; McAfee, 2013). However, it has been shown to be poorly implemented in Australia (Kelly, 2010). This and other criticisms of engagement practices have seen the recently changed Victorian Local Government Act set community engagement as one of its key reforms. This Act ensures that engagement, at a level that experts (e.g., IAP2, 2019) have deemed more than just information provision, be a central aspect of all local government decision-making. Compliance with legislation prior to statutory change, including providing proof of community support to councillors, required the following engagement activities by the Greening the Greyfields team formed at the City of Maroondah:

- A municipally approved communications strategy

- Greening the Greyfields personnel at all municipal events; ten events over two years, talking to more than 4000 residents, enabling a vote on the concept's value, and broadly socialising greyfield precincts within the local community 
- Web presence on municipal website; an information and voting page for residents

- Co-creation of design typologies; precinct additionality discussion and communication with a community advisory group

- Developer outreach to socialise the process to builders and developers locally

As well as adhering to the engagement tenets of the Act, these activities, and the resulting data in the form of community voting, written comments, and engagement metrics, satisfied both municipal management and councillors that the community supported the project.

\subsection{Landowner Engagement in Pilot Precincts}

Those engagements just described are principally related to satisfying government business logics rather than the true intent of community engagement: empowering citizens to take greater control of the governance associated with their local areas. A more 'grass-roots' style engagement, aimed explicitly at landowners in pilot precincts, took the form of what were termed 'town hall' and 'kitchen table' engagement activities.

Town hall engagement involved hosting publicly advertised open-house events in municipal buildings close to, or within, the pilot precincts; the aims being to ensure that residents knew about the proposed changes to the local planning scheme and to answer any questions residents had about the changes. Each open-house event ran over two days and contained an interactive map of the precinct and the planned additionalities, computer-rendered urban design illustrations of the precinct (pre- and post-development), a voting system for support or opposition to the system, and technical information sheets for dissemination. All landowners within and abutting the precinct were sent written invitations to the open-house sessions two weeks prior. Approximately half attended.

Kitchen table engagement occurs when residents are interested in the process and want to have a discussion with neighbours, municipal officers, and developers about their options. The aim of these meetings in this project was to work towards consolidating lots that represent a 
mutually beneficial outcome. The complexities and legalities of land amalgamation, combined with the ethical limits of applied research, meant that, at this point, academic control of the research project ceased, and it became a business process managed by industry professionals. However, to ensure the process had an ongoing engagement methodology (the components of which are illustrated in Fig. 7.10), a set of three playbooks was drafted to be used variously by landowners (to begin the process of land assembly with neighbours), developers (to define the product and its concessions and obligations), and municipalities (to achieve the same outcomes without researcher involvement-effectively the full Greening the Greyfields methodology). The playbook for landowners covered issues such as:

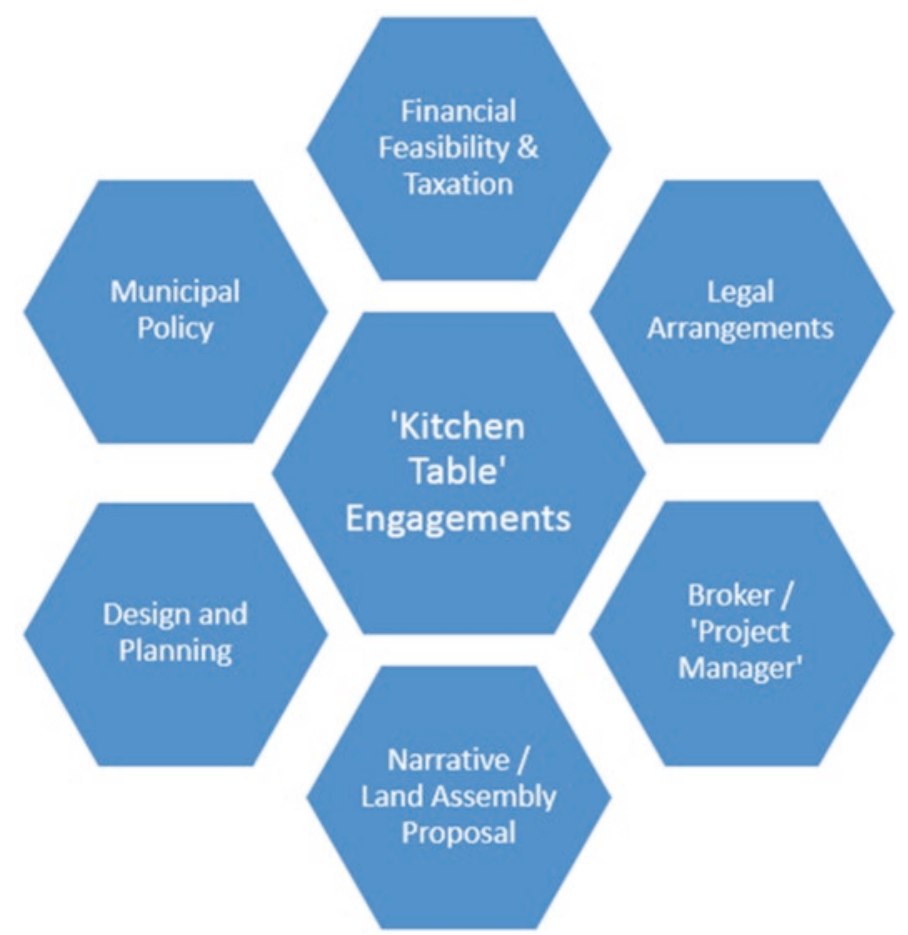

Fig. 7.10 Overview of the dimensions of landowner engagement required for lot consolidation and to instantiate GPR as a planning regime. (Source: Newton et al., 2020) 
- Municipal strategic planning objectives: Short-, medium-, and longterm objectives for change in particular neighbourhoods.

- Land-assembly proposal: Neighbourhood-specific, with a narrative illustrating the range of potential development outcomes and their benefits, including coordinated single sales, staggered sales, joint sales, land assembly and sale, land assembly with planning approval, or development.

- Legal arrangements: Range of group organisation options, including non-binding memorandum of understanding, partnership, landowners' cooperative/trust, developer joint venture, and incorporation.

- Brokering: Who will be managing each aspect of the process, including the landowner negotiations, planning, consolidation, and sales.

- Design and planning: Key steps if property owners want to consider more than selling land; for example, co-design and co-development.

- Financial feasibility: Increased complexity leads to greater costs, particularly if the landowner group wishes to move into planning and development. Landowners need to understand the costs involved and whether they are able to undertake more than land sale.

- Tax assessment: Before committing themselves to the process, landowners need to understand the tax implications of property sale (and possibly development).

These have been finalised and are available on the Greening the Greyfields project website (Greyfields 2020; https://greyfields.com.au).

\subsection{Engagement with Developers}

Developers were integrated into the engagement work in four areas. The first involved their inclusion in a community advisory group, where precinct location and additionality were debated. Here, developers were simply a voice of the community. The second was during the creation of 
the housing typologies and feasibility assessments, where developers provided commentary on dwelling design and reviewed the assumptions related to financial feasibility. The third was at internal (municipal) assessments of draft statutory amendments and, in particular, the developer contribution plans. This aspect was particularly telling, with the key messages being, first, that developers simply wanted to know the rules of the system, after which they would make their own assessments; and second, that the additional cost of the developer contribution (to fund precinct additionality) would easily be offset by either preapproved designs or exempting precinct-scale developments from notification, objection, and third-party review. However, as also indicated by Chandler (2016, p. 1), developers stated that greyfield precinct scale redevelopment was not typical:

Australia's housing industry has some serious shortcomings that can no longer be avoided.... The capabilities needed to design and build small scaled medium density housing projects of three to 10 dwellings up to three storeys atop below grade parking have yet to be developed. If medium density dwellings of the type described here are to make up a third of the housing landscape, a new marketing platform and delivery model will be required. These will not be offered from the traditional builder display village. New design, procurement and construction skills will be necessary. Only financially viable builders who display a new level of professionalism will be trusted to take on these projects. The industry must shift from its current level of denial of these realities. If governments are seriously minded to harvest the potential of greyfield sites and the urban middle, they will not only need to bring the community along in support of these more modest densification initiatives, they will need to be proactive in making sure the housing industry has the capabilities to deliver them. This is a challenge for the housing industry. It is not a market that general contractors understand or have an aptitude for. This is an opportunity for the first movers in this space to realise the potential of adapting their old project housing delivery model into a modern version of 'build to order' multiunit. (Chandler, 2016, p. 1) 
The GPR development arena needs a range of interventions at the builder/developer level. As outlined by Chandler (2016), the next set of issues to overcome is for the industry to up-skill into this new market.

\section{Conclusion}

GPR faces multiple barriers to entry that necessitate new process interventions such as those that have been outlined in this chapter:

- Locating prospective regeneration precincts in collaboration with local government and situating them in municipal strategic plans and housing strategies (i.e., 'where')

- Creating innovative medium-density dwelling designs appropriate to higher-density precinct living in the middle greyfield suburbs that can deliver significant additionality beyond small-lot subdivision: regenerative redevelopment and a new urban fabric more aligned to urbanising suburban landscapes (i.e., 'what')

- Making GPR less risky from state and local government, developer and property owner perspectives via a set of development overlays and design guidelines that can deliver appropriate regenerative redevelopment through new partnerships and processes (i.e., 'how')

All Australian planning agencies are committed to public-good goals established for Australian cities: sustainable, liveable, inclusive, resilient, and productive. However, there is a significant lack of attention to trying new ways of delivering such challenging goals. A set of GPR planning concepts, strategies, and practices have been set out in this chapter and a trial has begun in one municipality in Melbourne. A greater commitment to greening the greyfields is required through demonstration projects like the one in the City of Maroondah to increase the experience of how to transform greyfields on a precinct basis. There is currently a lack of the transformative capacity in state and local governments needed for the 
delivery of new models of urban transport and housing development such as place-activated and transit-activated GPR. The final chapter further explores GPR transition processes to drive change.

\section{References}

Aulich, C. (2009). From citizen participation to participatory governance in Australian local government. Commonwealth Journal of Local Governance, 2, 44-60.

Chandler, D. (2016). Shutting the garage door after the car has bolted. Sourceable. Retrieved 10 November 2020, from https://sourceable.net/ shutting-the-garage-door-after-the-car-has-bolted/

Crabtree, L. (2018). Self-organised housing in Australia: Housing diversity in an age of market heat. International Journal of Housing Policy, 18(1), 15-34.

CRCWSC. (2021). Water sensitive outcomes for infill development final report (Project IRP4). CRC for Water Sensitive Cities.

IAP2-International Association for Public Participation. (2019). Spectrum. Retrieved 27 February 2020, from https://www.iap2.org.au/resources/ spectrum/

Jarvis, D., Berkeley, N., \& Broughton, K. (2012). Evidencing the impact of community engagement in neighbourhood regeneration: The case of Canley, Coventry. Community Development Journal, 47, 232-247.

Kelly, J. (2010). Cities: Who decides? Gratten Institute.

Lawson, L., \& Kearns, A. (2010). Community engagement in regeneration: Are we getting the point? Housing and the Built Environment, 25, 19-36.

Litman, T. (2018). Transportation land valuation. Victorian Transport Policy Institute.

Marshall, A. J., Grosea Nicholas, M. J., \& Williams, S. G. (2019). From little things: More than a third of public green space is road verge. Urban Forestry \& Urban Greening, 44(6), 126423.

McAfee, A. (2013). Tools for change: CityPlan Vancouver's strategic planning process. Built Environment, 39, 438-453.

Melbourne Water. (2020). Melbourne Water's STORM calculator. Retrieved 10 March 2021, from https://storm.melbournewater.com.au/

Murray, S., Bertram, N., Khor, L.-A., Rowe, D., Meyer, B., Murphy, C., Newton, P., Glackin, S., Alves, T., \& McGauran, R. (2015). Processes for developing affordable and sustainable medium-density housing models for grey- 
field precincts. AHURI, Final Report No. 236. Australian Housing and Urban Research Institute Limited.

Nello-Deakin, S. (2019). Is there such a thing as a 'fair' distribution of road space? Journal of Urban Design, 24(5), 698-714. https://doi.org/10.1080/ 13574809.2019 .1592664

Newton, P. (2019). The performance of urban precincts: Towards integrated assessment. In P. Newton, D. Prasad, A. Sproul, \& S. White (Eds.), Decarbonising the built environment: Charting the transition (pp. 357-384). Palgrave Macmillan.

Newton, P., Glackin, S., Witheridge, J., \& Garner, L. (2020). Beyond small lot subdivision: Pathways for municipality-initiated and resident-supported precinct-scale medium-density residential infill regeneration in greyfield suburbs. Urban Policy and Research, 38(4), 338-356P.

Newton, P., \& Taylor, M. (2019). Precinct design assessment: A guide to smart sustainable low carbon urban development. Cooperative Research Centre for Low Carbon Living.

Newton, P., \& Tucker, S. (2011). Pathways to decarbonising the housing sector: A scenario approach. Building Research and Information, 39(1), 34-50.

Newton, P. W., \& Tucker, S. N. (2010). Hybrid buildings: Transitioning to zero carbon housing. Architectural Science Review, 53(1), 95-106.

Palmer, J. (2020). Realising collective self-organised housing: A network agency perspective. Urban Policy and Research, 38(2), 101-117.

Planning Panels Victoria. (2021). Maroondah Planning Scheme Amendments C134maro \& C136maro, Greening the Greyfields. Panel Report. 9th Aug. Victorian State Government. https://www.maroondah.vic.gov.au/files/assets/ public/documents/planning-health-local-laws/statutory-planning/ maroondah-c134maro-and-c136maro-panel-report.pdf

Renouf, M. A., Moravej, M., Sainsbury, O., Lam, K. L., Bertram, N., Kenway, S. \& London, G. 2019. Quantifying the hydrological performance of infill development. OzWater. Australian Water Association. Retrieved 2 March 2021 from https://watersensitivecities.org.au/content/project-irp4/

Sharam, A. (2016). Deliberative development: Australia's Baugruppen movement and the challenge of greater social inclusion. Housing Studies, 35(1), 107-122.

Thomson, G. (2016). Transitioning to regenerative urbanism. PhD Thesis. Curtin University. 
Open Access This chapter is licensed under the terms of the Creative Commons Attribution 4.0 International License (http://creativecommons.org/ licenses/by/4.0/), which permits use, sharing, adaptation, distribution and reproduction in any medium or format, as long as you give appropriate credit to the original author(s) and the source, provide a link to the Creative Commons licence and indicate if changes were made.

The images or other third party material in this chapter are included in the chapter's Creative Commons licence, unless indicated otherwise in a credit line to the material. If material is not included in the chapter's Creative Commons licence and your intended use is not permitted by statutory regulation or exceeds the permitted use, you will need to obtain permission directly from the copyright holder.

(c) (i) 